MONIKABORYS

Rasa, klasa, płeć i wieś. Feministyczne epistemologie marginesu

W moim artykule próbuję odpowiedzieć na pytanie, w jaki sposób polski feminizm mógłby poszerzać wiedzę i włączać w obszar swoich działań mieszkanki wsi. W tym celu przywołuję teorie z obszaru czarnej myśli feministycznej oraz postkolonializmu, które problematyzują epistemologię podporządkowanych. Aby renegocjować reżimy widzialności, które ograniczają naszą wyobraźnię, proponuję aplikację tych narzędzi do analizy popkulturowych reprezentacji wsi (film dokumentalny Warszawa do wzięcia oraz serial dokumentalny Chtopaki do wzięcia). Czerpiąc z teorii marginesu bell hooks, postkolonialnych krytyk Gayatri Chakravorty Spivak oraz idei wiedz usytuowanych autorstwa Donny Haraway, pomagających nam wzbogacać wiedzę o różnych rodzajach opresji i ich intersekcjonalności, chciałabym skierować uwagę czytelniczek na te wymiary seksizmu, które nie mieszczą się być może w wąskich ramach definicji „problemów kobiet z dużych miast”.

Słowa kluczowe: wieś, teoria marginesu, podporządkowani inni, wiedze usytuowane, intersekcjonalność 
W wywiadzie pt. Obca w krainie patriarchatu ${ }^{1}$, udzielonym tygodnikowi „Przegląd”, Agnieszka Graff opowiada o polskim feminizmie, swoich afiliacjach i dostrzeganym przez nią braku wrażliwości ekonomicznej w działaniach Kongresu Kobiet. Graff, która próbuje zdefiniować swoją pozycję w dzisiejszych debatach feministycznych, określa się jako „lewicowa wypustka w liberalnym Kongresie Kobiet”, krytykując jednocześnie jego ignorancję w kwestiach klasowych. Jednak mimo krytycznej oceny głównego nurtu feminizmu, kiedy w rozmowie pojawia się temat wykluczeń dotyczących kobiet ze wsi, Graff ostrożnie stwierdza, że patriarchat poza miastem nie był i jakoby nie może być obiektem działań feministek, że feminizm na wsi miałby charakter „misji kolonizacyjnej”. Na pytanie, jak feministki mogą dotrzeć do kobiet spoza dużych miast i głównych ośrodków akademickich, Graff odpowiada, że hermetyczność języka feminizmu akademickiego uniemożliwia dotarcie feministkom do ludzi wykluczonych z obiegu kultury, oraz że na tym polu należy oczekiwać raczej działań aktywistów i aktywistek, jak również zmian w ramach istniejącego prawa. Autorka Świata bez kobiet zapytana o jej własną wizję feminizmu, który skupiałby się również na problemach dyskryminacji kobiet ze wsi, odpowiada:

Kobiecie, która jest ofiarą przemocy, może pomóc dobre prawo i informacja o dostępnym wsparciu. O to polski feminizm walczy od początku lat 90 . O to, żeby w polskim prawie były wyraźne zapisy dotyczące np. izolowania sprawców przemocy. To jest dla kobiet na wsi kluczowe, żeby taka kobieta nie musiała być nieustannie w obecności sprawcy. To nie oznacza, że mam obowiązek do tej kobiety docierać i ją na feminizm nawracać. W takim podejściu byłby zresztą paternalizm, niezgoda na konserwatyzm, potrzeba nawracania. Ja nikogo nawracać nie chcę².

W moim tekście postaram się pokazać, że w analizie struktur patriarchatu należy ujawniać jego wielowymiarowe działanie, że warto wychodzić poza kwestie dotyczące jedynie kobiet z tzw. klasy średniej. Czerpiąc z dorobku czarnego feminizmu i postkolonializmu, których narzędzia pomagają wzbogacić wiedzę o opresji dotyczącej różnych kobiet, chciałabym skierować uwagę czytelniczek na te wymiary seksizmu, które nie mieszczą się być może w wąskich ramach definicji „problemów kobiet z dużych miast”. Uważam rewizję uniwersalizmów, w jakie wikła się

1 A. Graff, Obca w krainie patriarchatu, rozm. przepr. K. Leśniewicz, tygodnik „Przegląd” 2013, nr 26, http://www.przeglad-tygodnik.pl/pl/artykul/ obca-krainie-patriarchatu-rozmowa-agnieszka-graff.

2 Tamże. 
polski feminizm, za palące zadanie. Sądzę, że polska wieś potrzebuje nie tylko działań ukierunkowanych na walkę z wykluczeniem społecznym, ale również rzetelnej analizy uwzględniającej kwestię płci. Jako że jestem kulturoznawczynią, w moim eseju przyjrzę się wytworom współczesnej kultury popularnej, które dotyczą polskiej wsi. Serial paradokumentalny Chtopaki do wzięcia oraz film dokumentalny pt. Warszawa do wzięcia, które analizuję, postrzegam nie tylko jako pewne zestawy znaków i symboli, ale również jako opowieści i obrazy - reprezentacje - mające swoje jak najbardziej materialne skutki, tzn. legitymizujące struktury opresji i wzmacniające je.

Sądzę, że warto poddawać uważnemu i krytycznemu oglądowi współczesne teksty kultury popularnej, używając w tym celu teorii akademickich. Renegocjacja sensów tworzonych w popkulturze, rewizja konstruowanych wyobrażeń, ma - na co niejednokrotnie wskazywały bell hooks czy Angela Davis - ogromne znaczenie dla upowszechniania wiedzy.

\section{Epistemologia marginesu}

We wstępie do pierwszego wydania Teorii feministycznej: Od marginesu do centrum z 1984 roku bell hooks pisze, że książka ta powstała w odpowiedzi na postulaty amerykańskiego białego feminizmu, którego przedstawicielką była m.in. Betty Friedan, autorka fundującej dla tego nurtu publikacji z 1963 roku pt. Mistyka kobiecości. Feminizm liberalny, z którego wywodziła się Friedan, nie uwzględniał kwestii rasy i opresji rasistowskiej wobec kobiet, jego uwaga zwrócona była wyłącznie na problemy białych kobiet z klasy średniej. Perspektywa, którą w swojej książce przedstawia bell hooks, jest odpowiedzią na zasadniczy brak w feministycznej analizie liberałek, analizie, która nie uwzględnia tego, co znajduje się na marginesach. hooks domaga się poszerzenia perspektywy feministek, pokazując, że obok opresji seksistowskiej, w równej mierze dotyka kobiety klasizm i rasizm, a wszystkie rodzaje dominacji przenikają się, oddziałują na siebie i, co więcej, wyrastają ze wspólnych fundamentów. hooks formułuje krytyczną teorię feministyczną, która jest odpowiedzią rozbijającą esencjalne rozumienie kobiecości, wzmacniane przez liberalny amerykański feminizm, nieuwzględniający społeczno-kulturowego kontekstu, w którym każda z nas funkcjonuje.

3 b. hooks, Teoria feministyczna: Od marginesu do centrum, tłum. E. Majewska, Warszawa 2013, s. 6. 
bell hooks rozbija dotychczasową monolityczną definicję potrzeb kobiet, wzbogacając zarazem feministyczną epistemologię. Ten ruch jest oporem wobec ślepego cięcia - jednowymiarowego prezentowania sytuacji kobiet, dokonywanego przez liberałki, które definiowały patriarchat, dostrzegając wyłącznie jeden rodzaj ucisku, czyli seksizm. Ustanowiły w ten sposób hierarchię opresji, spychając rasę i klasę na pozycje mniej istotnych czynników, nadających strukturę mechanizmom władzy. W rezultacie liberalne amerykańskie feministki wzmacniały system dominacji, a feminizm czyniły rasistowskim.

Mówienie

z marginesu, którego hooks jest

przedstawicielką,

to pozycja, która

upodmiotawia

wykluczonych

i wykluczone,

ponieważ jest

wyrazem oporu wobec skostniałego i jednowymiarowego

systemu wiedzy

tworzonego w

centrum

- amerykańskiego

feminizmu

liberalnego

wykształconych,

heteroseksualnych,

białych kobiet
Autorka Marginesu jako miejsca radykalnego otwarcia przypomina, że rzeczywistość jest wieloaspektowa i zniuansowana, a postulaty znajdujące się na sztandarach białych feministek z klasy średniej, domagających się w zasadzie wyłącznie prawa do robienia kariery zawodowej, mają niewiele wspólnego z potrzebami kobiet $\mathrm{z}$ klas niższych i kobiet o innym kolorze skóry. Betty Friedan i jej zwolenniczki ujednoliciły doświadczenia kobiet, utożsamiając własne doświadczenia z doświadczeniami ogółu kobiet. Mówienie z marginesu, którego hooks jest przedstawicielką, to pozycja, która upodmiotawia wykluczonych i wykluczone, ponieważ jest wyrazem oporu wobec skostniałego i jednowymiarowego systemu wiedzy tworzonego w centrum - amerykańskiego feminizmu liberalnego wykształconych, heteroseksualnych, białych kobiet.

Umieszczenie siebie na marginesie chciałabym traktować i wykorzystać tu jako możliwość artykułowania sądów stojących w opozycji do polskiej feministycznej narracji głównego nurtu, jako szansę spojrzenia na wieś z takiej perspektywy, która pomoże mi wskazać miejsca opresji i miejsca epistemicznej przemocy.W krytycznej analizie kulturowych reprezentacji, którą postaram się w tym tekście przeprowadzić, będzie to gest wzbogacania epistemologii podporządkowanych - próba poszerzania dyskursu i wyjście poza taką jego dramaturgię i ekonomię, która sytuuje mieszkankę i mieszkańca wsi w pozycji niemych innych.

Ideę epistemologii oddolnych jako obiektywności feministycznej rozwijała m.in. Donna Haraway. Polemizując z neutralnością wiedzy i upatrując w wiedzach usytuowanych alternatywy dla pozornie obiektywnego „spojrzenia znikąd”, należącego do męskiego zachodniego badacza, Haraway pisała, że „istnieją dobre powody, by sądzić, że lepiej widzi się spod rozświetlonych platform, po których przechadzają się możni” “. Jak jednak ustrzec się przed niebezpieczeństwem uromantycznienia i przywłaszczania głosu rolniczek? Co zrobić, by feminizm zwrócony

4 D. Haraway, Wiedze usytuowane, tłum. A. Czarnacka, http://www.ekologiasztuka.pl/pdf/f0062haraway1988.pdf. 
w stronę mieszkanek wsi nie stał się „neokolonializmem feministycznym”, przed którym przestrzega w przywoływanym wywiadzie Agnieszka Graff? W jaki sposób, rozszerzając analizę krzyżujących się relacji władzy, pamiętać jednocześnie o naszych ograniczonych możliwościach poznawczych?

Fundamentalne pytanie o możliwość usłyszenia skolonizowanej ludności zadaje Gayatri Chakravorty Spivak. W swoim słynnym eseju Czy podporzadkowani inni moga przemówić? (Can the Subaltern Speak?) teoretyczka postkolonialna rozwija pojęcie subaltern używane w kręgu hinduskich studiów Subaltern Studies Group. Badacze i badaczki z Indii zaczerpnęli ten termin od Antonia Gramsciego, włoskiego marksisty, który używał określenia classi subalterne, by opisać tę część społeczeństwa, która poddana jest hegemonicznej represji. Zdaniem Spivak krytycy postkolonialni błędnie założyli, że mają dostęp do głosu podporządkowanych, że mogą ich usłyszeć. Podporządkowani inni to nie tylko, jak u Gramsciego, klasy zależne, ale ci, którzy nie mogą o sobie stanowić. Są wykluczeni i pozbawieni dostępu do sfery symbolicznej, w której dokonuje się ich definiowanie. Autorka Strategii postkolonialnych zwraca uwagę, że podporządkowana inna zyskuje swoją reprezentację formułowaną z zewnętrznej perspektywy, z punktu widzenia kogoś, kto znajduje się w innym kontekście geograficznym, ekonomicznym i społeczno-kulturowym.

Chęć uprzywilejowania konkretnego doświadczenia, próba usłyszenia czy nawet oddania głosu kobiecie ze wsi wymaga jednoczesnej problematyzacji warunków możliwości jej reprezentowania. Sądzę, że należy przy tej okazji zadać szereg pytań, które pomogą wzbogacić krytykę feminizmu, zrewidować jego liberalne podstawy, w oparciu o które wytwarzany jest kobiecy podmiot i target polskiego feminizmu. Czy kobieta ze wsi sama się reprezentuje, czy zdana jest na reprezentację? Czy może, jak mówił w rozmowie z Michelem Foucaultem Gilles Deleuze, „nie ma już reprezentacji, tylko działanie - działanie teoretyczne i działanie praktyczne, które odnoszą się do siebie, przejmując od siebie pałeczkę i tworząc sieci"'?

Wchodząc w polemikę z Foucaultem i Deleuzem, Spivak pokazuje, jak doświadczenie podporządkowanych innych jest konsekwentnie wykluczane przez tych, którzy tworzą epistemologię marginalizowanych. Foucault i Deleuze, mimo że dokonują krytyki suwerennego podmiotu

5 G.Ch. Spivak, Czy podporządkowani inni moga przemówić, tłum. E. Majewska, „Krytyka Polityczna” 2011, nr 24/25.

6 Intelektualiści a wtadza (rozmowa między Michelem Foucault a Gilles'em Deleuze’em), tłum. S. Magala, „Miesięcznik Literacki” 1985, nr 11. 
i szukają głosu Innego, jednocześnie nie wskazują na własne uwikłania i zależności. W takiej sytuacji reprezentacja zdominowanych, konstruowana przez twórców, intelektualistów, tzw. dysponentów znaku, staje się miejscem epistemicznej przemocy. Portretowana podczas procesu dekolonizacji przez francuskiego intelektualistę brązowa kobieta nie może być usłyszana. Reprezentacja, posługując się szeregiem uproszczeń, esencjalizacji, uprzedzeń i fantazmatów, fabrykuje naszą wiedzę, która ma uchodzić za bezstronną. Portret ukazywany jest jako obiektywny, niedyskutowalny i uniemożliwia usłyszenie głosu kobiety z Indii.

Ustaleniu, jak możemy usłyszeć, co do powiedzenia ma kobieta ze wsi oraz w jaki sposób możemy wzbogacić wiedzę o jej rzeczywistości, powinno, jak sądzę, towarzyszyć krytyczne zbadanie sposobów konstruowania jej reprezentacji, wnikliwa analiza definicji, które pochodzą od definiujących, a nie od definiowanych. Dlatego w tym tekście analizuję wytwory kultury, które nie dopuszczają do głosu mieszkanek i mieszkańców wsi. Mam wrażenie, że krytyczny ogląd tych obrazów, analizowanych tu za pomocą narzędzi z obszaru studiów postkolonialnych i czarnej myśli feministycznej, może pomóc nam oswoić się z sytuacją, kiedy głos dotyczący wsi przychodzi do nas z zewnątrz, kiedy jest zapośredniczony.

Trudna sytuacja dystansu wzmaga pokusę tworzenia „obiektywnej”, uniwersalizującej wiedzy, definicji, które ubiegają się o miano prawdy. Perspektywie znikąd, spojrzeniu „cyklopowego oka”, Haraway przeciwstawia usytuowanie teorii, które w rozważaniach bell hooks polega na ciągłej walce o możliwość artykulacji własnej perspektywy, popartej konkretnymi doświadczeniami, ale z równoczesną świadomością, że w tej walce narzędziem jest ciągle język skażony uniwersalizmem. Czytając książki autorki Marginesu jako miejsca radykalnego otwarcia czujemy, że w każdym zdaniu stara się ona zwrócić uwagę na uwikłanie języka i jego nieprzezroczystość, na jego pozorną homogeniczność. „Język jest także polem walki" ${ }^{8}$, powtarza z uporem hooks. Walczy o nowy - jej własny - sposób mówienia o przemocy i opresji. Nie zapomina i jednocześnie nie pozwala nam zapomnieć, że posługujemy się językiem ciemiężcy - systemem, który uwikłany jest w przemoc symboliczną. To pisanie/działanie ma charakter transgresyjny, ma przekraczać granice wyznaczone przez narzucone definicje.

Produkcja wiedzy zachodzi zawsze w konkretnym kontekście społeczno-kulturowym i określonym momencie historycznym, co oznacza,

7 D. Haraway, Wiedze usytuowane...

8 b. hooks, Margines jako miejsce radykalnego otwarcia, tłum. E. Domańska, „Literatura na Świecie” 2008, nr 1/2, s. 109. 
że wiedza jest ograniczona i nie posiada charakteru uniwersalnego, jak być może chciałby zachodnioeuropejski/amerykański biały męski badacz. Tu m.in. bierze swoje początki opresja - wynika z uniwersalizacji własnych doświadczeń, niewidzialności uwarunkowania/usytuowania każdego osądu i rozciągania przez teoretyka/teoretyczkę własnej perspektywy na całość.

Reprezentacje polskiej wsi często stają się miejscem przemocy epistemicznej. Dzieje się tak na przykład wtedy, gdy trudne doświadczenia rolników z popegeerowskich gospodarstw opisywane są za pomocą języka neoliberalnej elastyczności, konkurencyjności i postępu albo gdy proces migracji młodzieży ze wsi do miasta, ich szybki awans społeczny, diagnozowany jest jedynie z perspektywy miasta. Ryzyko wykluczenia konkretnego doświadczenia jest większe, kiedy dochodzi do redukcji znaczeń gromadzonych wokół wsi w rzeczywistości społeczno-kulturowej. Uprzedzenia żywione wobec niej - wypowiadane w języku neoliberalizmu - zostały zredukowane do wąkiego i przewidywalnego repertuaru skojarzeń, znaków i obrazów, które razem współtworzą pewien nieustannie reprodukowany reżim reprezentacji.

bell hooks patrzy na margines jako miejsce wytwarzania oporu, przestrzeń kontrhegemonicznej ekspresji i narzędzie wzbogacania epistemologii podporządkowanych. Postulując usytuowanie wiedzy oraz konieczność i prawo do ujawniania pozycji, z której jest ona produkowana, hooks podkreśla zarazem, że nie wolno zapominać o kolonizatorskiej przeszłości języka, w którym tę wiedzę tworzymy - o jego skażeniu stereotypem i zapisanym w nim piętnie opresji. Jest to walka z językiem i o język jednocześnie. Sądzę, że podobną walkę w odzyskiwaniu obrazów wsi należy stoczyć na polu estetycznym. Istnieje niebezpieczeństwo, że poszukiwania głosów mieszkańców i mieszkanek prowincji mogą zatrzymać się na znanych powszechnie kliszach. Dekolonizacja może również nie oprzeć się urokowi polaryzującego języka, który, prezentując się jako naturalny, niepodważalny i niedyskutowalny, bardzo często powiela dwubiegunowy model polskiej kultury panów i chamów.

\section{Porażka reedukacji. Warszawa do wzięcia}

Warszawa, pierwsze lata dwudziestego pierwszego wieku. W ośrodku prowadzonym przez Caritas siedzi grupa młodych kobiet, które przyjechały do stolicy w ramach programu aktywizacji zawodowej przeznaczonego dla dziewcząt z popegeerowskich wsi. Zgromadzone wokół ekspertki od zasad savoir-vivre’u słuchają pouczeń, jak mają ubrać się 
na rozmowę kwalifikacyjną, jak nakładać masło na chleb i w jaki sposób jeść kurczaka. Wśród nich siedzą Ania, Gosia i Ilona - bohaterki filmu Warszawa do wzięcia w reżyserii Julii Ruszkiewicz i Karoliny Bielawskiej.

Dziewczyny wzięły udział w projekcie, który określony został w 2002 roku przez ministra pracy i polityki społecznej Jerzego Hausnera jako "przepustka ze wsi do miasta”" . „Promocja zawodowa dziewcząt. Przystań na skarpie” stworzona została przez Caritas Archidiecezji Warszawskiej i współfinansowana przez Agencję Własności Rolnej Skarbu Państwa. W programie adresowanym do bezrobotnych z popegeerowskich wsi w latach 2001-2009 wzięło udział około sześciuset dziewczyn, wśród nich były trzy bohaterki Warszawy do wzięcia.

Moja analiza poświęcona „Przystani na skarpie” będzie dotyczyć zarówno projektu, czyli pewnych instytucjonalnych mechanizmów, które umacniają dystynkcje w społeczeństwie, jaki i samej narracji filmowej, która budując swoją dramaturgię na opozycji wieś-metropolia, utrwala kreowaną „inność” mieszkanek popegeerowskich wsi. Ponadto, co postaram się pokazać, ze względu na szeroko projektowaną ingerencję w tożsamość potencjalnych uczestniczek programu aktywizacji, można tenże program interpretować jako proces wymuszania mimikry, czyli takiej relacji dominacji, która ma modelować podporządkowane na warunkach dyktowanych przez kolonizatora ${ }^{10}$.

Projekt opatrzony hasłami wyrównywania szans i pomocy w rozwoju osobom z terenów popegeerowskich jako swój cel wyznacza „adaptację do warunków dużego miasta, intensywną aktywizację zawodową, uzyskanie zatrudnienia i usamodzielnienie w Warszawie"11. Odbiorcami tego przedsięwzięcia nie są jednak wszyscy mieszkańcy wsi, jest to określona grupa osób. Twórcy „Promocji zawodowej dziewcząt” jasno i szczegółowo definiują profil jego potencjalnych uczestniczek. Do warszawskiej bursy prowadzonej przez Caritas mogą przyjechać bezrobotne dziewczyny w wieku od osiemnastu do dwudziestu pięciu lat, których przynajmniej jedno z rodziców przepracowało trzy lata w Państwowym Gospodarstwie Rolnym. Ponadto wymogiem, który stawiają twórcy programu, jest stan wolny dziewcząt.

9 Informacje zaczerpnęłam ze strony caritas.pl, cytat pochodzi z nieopatrzonego nazwiskiem autora/autorki artykułu Caritas $i$ ministerstwo pracy pomagaja bezrobotnym dziewczętom, http://caritas.pl/caritas-archidiecezji-warszawskiej/1007-caritas-i-ministerstwo-pracy-pomagaja-bezrobotnym-dziewczetom.

10 H. Bhabha, Mimikra i ludzie: O dwuznaczności dyskursu kolonialnego, tłum. T. Dobrogoszcz, „Literatura na Świecie” 2008, nr 1/2.

11 http://www.femina.org.pl/index.php?option=com_content\&task=view\&id $=347 \&$ Itemid $=35$. 
Warto w tym miejscu zaznaczyć, że szczegółowo opisany, skategoryzowany profil uczestniczki programu ma służyć efektywnemu przeprowadzeniu tzw. reedukacji, czyli reformowaniu i zarządzaniu podmiotami. Wiedza-władza, znajdująca się po stronie twórców projektu, konstruuje w ten sposób widoczny, przewidywalny podmiot, który ma być poddany ujarzmianiu.

Pomoc oferowana dziewczynom polega na zapewnieniu im bezpłatnego (na dwa miesiące) miejsca zamieszkania, wyżywienia, biletu na warszawską komunikację miejską, szeregu szkoleń, pomocy w szukaniu ofert pracy, opiekę psychologa i doradcy zawodowego.

Realizowany w bursie program wychowawczy ma ponadto umożliwić dziewczętom zdobywanie i podnoszenie kwalifikacji zawodowych poprzez udział w kursach i szkoleniach oraz kształtowanie charakteru i odpowiednich zalet moralnych, przygotowujących do wejścia w sposób odpowiedzialny w dorosłe życie. Trzeba też zauważyć, że obecna sytuacja kandydatek: kwalifikacje zawodowe, cechy osobowościowe (poziom dojrzałości psychicznej, emocjonalnej, społecznej) będą czynnikami determinującymi skuteczność naszych działań, szczególnie specjalisty ds. rynku pracy ${ }^{12}$.

Założenia o tym, jakie są dziewczyny - definiowanie ich habitusów i wskazywanie ich braków - mają dawać uprawomocnienie celom programu, który nie tylko zakłada pomoc w znalezieniu pracy, ale przede wszystkim chce ingerować w tożsamość jego uczestniczek. Program nie był zorientowany na edukację jako taką - poszerzenie horyzontów, zdobycie informacji o możliwościach na warszawskim rynku pracy i przekwalifikowanie zawodowe. W swoich założeniach „Przystań na skarpie” nastawiona była na wypełnienie jakichś braków, które zdiagnozowane zostały po stronie dziewcząt. Rodzaj przeprowadzanych w bursie szkoleń, które oglądamy w Warszawie do wzięcia świadczy o tym, że dostrzeżone przez przełożonych i doradców bursy „niedostatki” dotyczyły przede wszystkim wyglądu dziewczyn, zasad savoir-vivre’u oraz konwenansów i reguł obowiązujących podczas rozmów kwalifikacyjnych.

W opisie programu czytamy, że Caritas pośredniczy w znajdowaniu zatrudnienia. W filmie jednak widzimy, że bohaterki same muszą szukać w gazecie ogłoszeń o pracy. Ania, Gosia i Ilona chodzą na rozmowy kwalifikacyjne do delikatesów nocnych, sklepów, na zmywak. Wytworzone jako podmioty taniej siły roboczej, trafiają do stolicy na warunkach dyktowanych przez instytucje państwowe i kościelne, zasilając

12 Zasady funkcjonowania Bursy Promocji Zawodowej „Przystań na Skarpie”, http://bursaskarpa.w.interia.pl/sam03.htm. Podkr. MB. 
szeregi pracowników i pracownic, których praca jest najsłabiej opłacana. W ten sposób realizuje się opisywany przez Wallersteina paradoks kapitalizmu $^{13}$. Marginalizowane grupy osób, dyskryminowane ze względu na płeć, pochodzenie i klasę społeczną, nie są wykluczone z systemu tzw. wolnego rynku, ale wręcz przeciwnie, będą w niego sukcesywnie wtłaczane, a koszty ich pracy możliwie najbardziej zmniejszone.

Reżyserki Warszawy do wzięcia deklarują, że najważniejsze w tworzeniu filmowego obrazu prób emigracji ze wsi do miasta były dla nich trzy bohaterki i to ich racje w filmie miały być najsilniej wyartykułowane. W wywiadzie udzielonym dwa lata po premierze - w momencie, kiedy żadna z trzech bohaterek nie przebywa w już Warszawie, ponieważ poszukiwania pracy każdej z nich zakończyły się fiaskiem - Ruszkiewicz i Bielawska zwracają uwagę, że niesłuszne są oskarżenia pod adresem dziewczyn, jakoby same były winne, że nie powiodło im się na warszawskiej „ziemi obiecanej”. „Wcale nie są same sobie winne, bo wychowały się w określonych warunkach. Mogę powiedzieć, że naprawdę nie wiem, kim byłabym, gdybym urodziła się w takiej rodzinie i wyrastała wśród takich wzorców." ${ }^{14}$ Zrozumienie, że los każdej i każdego z nas warunkowany jest przez czynniki społeczne, miesza się tutaj jednak ze stereotypowymi kliszami, które przenoszą uwagę z problematyzacji klasowych uwarunkowań na hasła naturalizujące kulturowy i ekonomiczny bagaż. W tej samej rozmowie twórczynie mówią: „To jest właśnie bieda mentalna, a nie materialna. W mieszkaniu jednej z bohaterek nie widać biedy. Co z tego, gdy nie wie, kim jest i czego chce. Tak się dzieje, ponieważ w domu rozmawia się tylko o tym, co ludzie powiedzą"15.

Ponad dwadzieścia lat po zamknięciu Państwowych Gospodarstw Rolnych język opisu ubóstwa i podziałów społecznych z nim związanych skupia się na obwinianiu za niepowodzenie neoliberalnego systemu nie mechanizmów gospodarki rynkowej, a jednostek, które mają stać się elastyczne, kreatywne i samowystarczalne. Warto też może zauważyć, że esencjalizujące obrazy, oprócz tych pochodzących z komentarzy, pojawiają się jednocześnie w samej płaszczyźnie filmowej. Warszawa i małe wsie ujęte są w uproszczony schemat opozycji, homogenizujący zarówno stolicę, jak i popegeerowskie marginesy.

13 Zob. I. Wallerstein, The Ideological Tension of Capitalism: Universalism versus Racism and Sexism, [w:] E. Balibar, I. Wallerstein, Race, Nation, Class: Ambiguous Identities, London-New York 1991.

14 K. Bielawska, J. Ruszkiewicz, Po co mieć plany, skoro i tak nic nie wychodzi: Co z bohaterkami "Warszawy do wzięcia”?, rozm. przepr. M. Gostkiewicz, http:// www.tokfm.pl/Tokfm/2029020,110500,9968111.html.

15 Tamże. Podkr. MB. 
Momenty, kiedy przenosimy się do Głodowa i Zalesia - wsi, w których do 1991 roku istniały Państwowe Gospodarstwa Rolne, to spokojne, statyczne kadry, którym towarzyszą pojedyncze, połamane dźwięki. W Warszawie zaś punktem centralnym reżyserki uczyniły galerię handlową Złote Tarasy. To na jej tle toczą się rozmowy dziewczyn o zmianach, jakie zaszły w ich życiu po przeprowadzce do stolicy, w końcu będzie to również miejsce pracy jednej z bohaterek.

\section{Pomiędzy}

Dyskurs władzy kolonialnej, wbrew pozorom stwarzanym przez wszelkie arbitralne polaryzacje i binarności, nie jest homogeniczną strukturą dominacji, wyznaczającą jej podmiotom stabilne pozycje. Jak podkreśla Bhabha, zarówno kolonizator, jak i kolonizowany nieprzerwanie negocjują swoją tożsamość. Proces mimikry pokazuje, że podporządkowani nie upodabniają się całkowicie do swojego opresora. Właśnie ze względu na ujawniające się pęknięcia i rozszczepienia wewnątrz władzy, proces mimikry interesuje mnie w tym miejscu najbardziej.

Mimikra, opisywana szeroko przez Homiego Bhabhę, to sytuacja, w której tożsamość skolonizowanego jest reformowana i porządkowana na wzór tożsamości kolonizującego. Dwuznaczność „misji cywilizacyjnej” polega na tym, że do pełnej identyfikacji Innego z jego opresorem nigdy nie dojdzie, zawsze będzie istniała między nimi nieusuwalna różnica. Tożsamość kolonialna jest kondycją „bycia pomiędzy”. Bhabha, czytając Czarną skórę, biate maski Franza Fanona, pisze: „To nie Kolonizujące Ja, ani Skolonizowany Inny, lecz niepokojąca przestrzeń pomiędzy jest podstawą kolonialnej figury inności - wytwór Białego wpisany w ciele Czarnego"16. Interpretacji tego rodzaju zawieszenia tożsamości jest kilka.

$\mathrm{Z}$ jednej strony, forma dyskursu kolonialnego, jakim jest mimikra, tworzy niezbywalny stygmat inności, różnicę, której naznaczony podmiot nigdy się nie pozbędzie, a która może stanowić narzędzie jego kontrolowania. Z drugiej strony, różnica może stać się narzędziem podporządkowanego, który za jego pomocą wyznacza całkowicie własny, niedostępny dla kolonizacyjnej zmiany obszar tożsamości. W takim rozumieniu różnica miałaby charakter emancypacyjny, antykolonialny. Jednak według Bhabhy byłaby ona nie tyle bronią w rękach opresjonowanego podmiotu, ile raczej wynikiem słabości samego dyskursu władzy:

16 H. Bhabha, cyt. za: A. Loomba, Kolonializm/Postkolonializm, tłum. N. Bloch, Poznań 2011, s. 187. 
„opór ten nie musi być wcale opozycyjnym aktem intencji politycznej [...], ale efektem dwuznaczności zaistniałej w ramach reguł uznania dyskursów dominujących, które artykułują znaki różnicy" ${ }^{17}$. Idąc dalej (a na taką perspektywę chciałabym zwrócić w tym momencie szczególną uwagę), przestrzeń „pomiędzy” jest miejscem oporu wobec dominacji, ponieważ stanowi moment, kiedy władza kolonialna ujawnia swoją słabość. Porażkę ponosi projekt, który opiera się na przekonaniu o wyższości „cywilizowanego” kolonizatora, którego kultura ma okazać się dla podporządkowanego słuszną i lepszą. Zmuszająca podporządkowanych do udawania, „doganiania”, mimikra nigdy się nie powiedzie, ponieważ, jak pisze Jan Sowa, „uprawiana przez kolonialny podmiot pod maską podobieństwa ukrywa niemożliwość identyczności”"

Spójrzmy na działania twórców „Przystani na skarpie” jako na proces mimikry, która, jako narzędzie wymuszania zależności, ma podwójny charakter. $\mathrm{Z}$ jednej strony tożsamość dziewczyn, czy to w założeniach programu, czy jako bohaterek filmu, konstruowana jest konsekwentnie w oparciu o figurę inności. Mimo że program opatrzony jest hasłami „wyrównywania szans”, a w filmie oglądamy sceny, w których Ania, Gosia i Ilona biorą udział w kursach i szkoleniach, to ciągle jednak prezentowane są one jako te, które trzeba pouczyć czy też douczyć - i nie jest to edukacja, która wykraczałaby swoim zasięgiem poza wiedzę, jak jeść bułkę i jak zachowywać się na rozmowie kwalifikacyjnej. Dziewczyny są również w bursie poddane nieustannej kontroli. Mimo że są pełnoletnie, muszą tłumaczyć się, o której wrócą, dokąd i po co idą. W filmie oglądamy również scenę, kiedy dwie dziewczyny sprzątają ośrodek, będąc pod nieustanną kontrolą opiekunki, sprawdzającej, czy z każdego zakamarka zniknął kurz.

Z drugiej strony mimikra to mechanizm, który przez niemożność całkowitego upodobnienia kolonizowanego do kolonizatora sam wskazuje na porażkę kolonizacji. Charakter antykolonizacyjny, konstytutywny dla mimikry, nie leży jednak całkowicie po stronie dziewczyn, które „nie doganiają stolicy”, ale polega na słabości samego programu „Przystań na skarpie” i jego chybionych założeń. Porażka ujawnia się w ciągłym napięciu zlokalizowanym w przestrzeni „pomiędzy”. Uczestniczki programu zawieszone są między popegeerowską wsią a Warszawą, między doświadczeniem bezrobocia a stolicą, która coraz szybciej kręci się w kołowrotku kapitalizmu, między zostawionymi na wsiach rodzinami,

17 Tamże, s. 188.

18 J. Sowa, Fantomowe ciato króla. Peryferyjne zmagania z nowoczesna forma, Kraków 2012, s. 470. 
często sceptycznie spoglądającymi na wyjazd, a przełożonymi z bursy, kobietami prowadzącymi kursy savoir-vivre’u i niedoszłymi szefami. Dziewczyny w swoich wypowiedziach co rusz zdradzają porażkę programu, który miał je wyposażyć w „podstawy” rzekomo niezbędne do funkcjonowania w stolicy. Nie podporządkowują się zasadzie decorum, organizującej rozmowę kwalifikacyjną, w myśl której należy zaprezentować się jako osoba elastyczna, kreatywna, bezkrytyczna wobec dyktowanych przez pracodawcę warunków pracy, gotowa na zmiany swojego dotychczasowego trybu życia.

Różnica między wsią i miastem, która zatopiona była w kategoryzacji uczestniczek programu pomocowego, utrwalona w ramach narracji filmowej, przenika i zostaje umocniona w recepcji Warszawy do wzięcia. Opis życia i losów dziewczyn w artykule pt. Dziewczyny z korzeniami autorstwa Edyty Gietki jest przesycony egzotyzującymi obrazami, które patologizują uczestniczki „Promocji zawodowej dziewcząt”. Konstruowana odmienność staje się w ramach tej opowieści przepaścią między wsią i Warszawą, a przestrzeń „pomiędzy” kanałem dla wykpiwającej, paternalistycznej narracji. Projekt Caritasu i Agencji Nieruchomości Rolnych oraz Warszawa do wzięcia, analizowane wspólnie, tworzą dyskurs, który wytwarza warunki zaistnienia artykułowanych pod adresem dziewcząt obraźliwych określeń. Autorka artykułu buduje w swojej opowieści obraz niewykształconej masy, dla której miasto to nie tyle miejsce edukacji i rozwoju osobistego, co raczej kraina upragnionej wolności. Gietka posuwa się nawet do nieprzyznawania dotychczasowej egzystencji emigrantek statusu życia, pisząc: „Pierwsze wynurzenie się sióstr W. z podziemi Dworca Centralnego można porównać do wrażenia więźniów wychodzących za bramę po kilku latach nieżycia"19.

\section{Małżeństwo seksizmu i klasizmu. Chłopaki do wzięcia}

Irena i Jerzy Morawscy w 2012 roku na zamówienie telewizji Polsat wyprodukowali serial Chtopaki do wzięcia. Po emisji dwóch odcinków w paśmie Polsat Play (które na swojej stronie internetowej określa się jako „kanał, który doskonale łączy męskie pasje i prezentuje całą gamę tematów interesujących każdego mężczyznę" ${ }^{20}$ ), okazało się, że pasmo

19 E. Gietka, Dziewczyny z korzeniami, http://www.polityka.pl/spoleczenstwo/reportaze/1500775,1,dziewczyny-z-pgr-u-do-warszawy.read.

20 http://www.polsatplay.pl/O_Nas,2908/Polsat_Play,2911/index.html. 
potroiło swoje udziały w rynku w stosunku do wiosny 2012 roku $^{21}$. W obliczu szybko rosnącej popularności serialu, który określał się mianem „reportażu” (obecnie tę etykietę zamieniono na „serial paradokumentalny”), przeniesiono emisję premierowych odcinków do głównego kanału telewizji Polsat. W 2013 roku Polsat podjął decyzję o produkcji kolejnych dwunastu odcinków serialu. Twórcy tak opisują tematykę swojej produkcji:

Młodzi mieszkańcy małych miasteczek i wsi poszukują partnerek na całe życie. Są w trudnej sytuacji, bo większość dziewczyn, które znali ze szkół, wyjechało do pracy do większych miast. One już nie wróca, zostały „miastowe”. Chłopcy zostali sami, pracują dorywczo, „bez zarejestrowania”. W soboty i niedziele spotykają się przed sklepami na wsiach, krążą po rynku małego miasteczka lub wystają na dworcach autobusowych. Prowincjonalna Polska utkana jest z biedy, nudy i beznadziei ${ }^{22}$.

Podobnie jak w przypadku wcześniejszego filmu Morawskich pt. Czekając na sobote, kolejna ich produkcja obiecuje swoim odbiorcom i odbiorczyniom, że pozwoli im dowiedzieć się czegoś o życiu i obyczajach matrymonialnych na polskiej prowincji. Po raz kolejny powtarzany jest gest, który ma budować wrażenie, że przed widzami ujawniane jest jakieś tabu. Tym razem kamera skupia się prawie wyłącznie na mężczyznach. Ich „poszukiwania” partnerek (program mówi wyłącznie o heteroseksualnych relacjach) to spiritus movens całej narracji, która w swojej poetyce nie odbiega od wyrytych w wyobraźni filmowców i widzów stereotypów dotyczących polskiej wsi. Bohaterowie i nieliczne bohaterki spetryfikowane zostają w podobiznach rodem z seriali komediowych i popkulturowych stereotypach powielanych co rusz w telewizji. Opowieść o zacofaniu, apatyczności i patologii prowincji wyprodukowana w poetyce neoliberalizmu, splata się tutaj z systemem patriarchalnym. Pod etykietką reportażu taki wytwór kultury popularnej jak Chtopaki do wzięcia umacnia seksistowskie schematy myślowe i praktyki, w których kobieta postrzegana jest jako obiekt do zdobycia, uprzedmiotowiona i sprowadzona do roli towaru w transakcji matrymonialnej. Obiecując neutralny, nieuprzedzony ogląd, generuje i utrwala kulturowe klisze.

Przesiąknięte szowinistycznymi treściami nie są jedynie wypowiedzi kawalerów - bohaterów, ale również, a może przede wszystkim, komentarze z offu, od „niewidzialnego” męskiego lektora, np. „Lew parkietu i pożeracz serc nie zna tych problemów. W kobietach przebiera jak

21 http://media2.pl/badania/97064-Chlopaki-do-wziecia-hitem-kanaluPolsat-Play-wideo.html.

22 Tamże. 
w ulęgałkach. Czy najnowsza znajoma - pani Ela - ma szansę na dłużej zagościć w sercu pana Stasia?”23. Rzekomo,„cywilizowany” autor okazuje się również uwikłany w seksistowski stereotyp.

Jak się okazuje, transakcja matrymonialna, na której ufundowana jest fabuła serialu reprodukującego stereotypowe imaginarium o wsi, spleciona dodatkowo z szowinistyczną perspektywą, stała się bardzo popularnym, przynoszącym telewizji Polsat wymierne zyski towarem.

W swojej analizie Chtopaków do wzięcia nie chcę zapytać jedynie o stosowność obrazów i komentarzy. Są one paternalistyczne, seksistowskie i obraźliwe. Chciałabym zastanowić się również, dlaczego takie przedstawienia nadal istnieją w przestrzeni publicznej. Jak wytwarzane są warunki możliwości funkcjonowania takiego przekazu w telewizji? W tym celu przywołam film afroamerykańskiego reżysera Spike’a Lee pt. Wykiwani, w którym twórca obnaża funkcjonowanie telewizyjnych reżimów widzialności.

\section{Nieśmiertelny blackface}

„Nakarmić głupie pudło” to mantra, którą powtarzał do siebie Pierre Delacroix, wgapiając się w ekran telewizora. Główny bohater Wykiwanych Spike'a Lee (oryg. Bamboozled, 2000 rok), alter ego niepokornego reżysera, podjął wyzwanie rzucone mu przez szefa dużego koncernu telewizyjnego CNS (Continental Network System), żądającego prawdziwego „murzyńskiego show”. Program wymyślony przez Delacroix miał być rozrywkową superprodukcją, która pobije na rynku amerykańskich stacji telewizyjnych wszelkie rekordy popularności. Delacroix - czarny absolwent Uniwersytetu Harvarda, zdeterminowany i w pełni świadomy jego ważących się w pracy losów, postanawia wykorzystać polecenie swojego białego szefa do obnażenia rasizmu, który na progu nowego wieku nadal istnieje w amerykańskim społeczeństwie. Licząc się ze wszelkimi kontrowersjami, rozważnie zakładając fiasko swojego przewrotnego pomysłu już po pierwszym odcinku i, ostatecznie, licząc się z utratą pracy, Pierre Delacroix decyduje się stworzyć show rasistowskie do granic możliwości. Wszystko po to, żeby obnażyć funkcjonowanie mechanizmów telewizji, która, jeśli chce widzieć Czarnych, to jedynie w postaci klaunów - postaci, do istnienia których Amerykanie się przyzwyczaili.

Delacroix przenosi w dwudziesty pierwszy wiek to, na czym ufundowany był amerykański show biznes, czyli minstrel show. Jest to szczególnie popularna w dziewiętnastym wieku forma teatralna, określana często jako

23 Chtopaki do wzięcia, odcinek 5. 
wodewil, wypełniona tańcem i piosenkami wykonywanymi przez białych aktorów, którzy malowali swoje twarze na czarno. Makijaż wykonywali z palonego korka, a usta przesadnie malowali czerwoną szminką. Tak karykaturalnie poprzebierani aktorzy odgrywali prześmiewcze gagi o czarnych, którym w tych przedstawieniach wolno było być jedynie głupimi, leniwymi niewolnikami z plantacji bawełny. Blackface jest więc nie tylko rodzajem maski - podobizny czarnego z dużymi ustami - wdrukowanej w wyobraźnię Amerykanów. To stereotypowe wyobrażenie, na które składa się zarówno przesadny makijaż, jak i zestaw określonych cech i predyspozycji, do których zredukowana została tożsamość Czarnego. To powszechnie znane klisze, które mają wykreślać przewidywalny, znany wszystkim model czarnych.

Mantan. Minstrel Show nowego millenium miał być, w myśl Delacroix, absurdalną, przerysowaną do granic satyrą, która zdekonstruuje i wyśmieje stereotypy o czarnych. Miał się też zakończyć po pierwszym odcinku. Jednak już po wstępnej emisji, stacja zamówiła kolejnych dwanaście odcinków. Nowy minstrel show okazał się strzałem w dziesiątkę, a telewizja CNS pobiła rekordy popularności. Krzywiąca się kurtuazyjnie na początku publiczność, po niedługim czasie zaczęła świetnie się bawić przy gagach tancerzy grających głupich pechowców na plantacji arbuzów. Sami aktorzy - uliczni artyści, którzy przed angażem do tej kasowej produkcji nie dojadali i mieszkali na skłocie, przenieśli się do apartamentowców. Pierre Delacroix nie przewidział takiego rozwoju sytuacji.

Spike Lee pokazuje w Wykiwanych, w jaki sposób blackface staje się dla telewizji doskonałym towarem, jak rasistowski stereotyp pod postacią popkulturowej, pozornie niewinnej opowiastki, podporządkowuje sobie ludzi i zniewala ich wyobraźnię. Szowinistyczne, obraźliwe wizerunki czarnych nigdy nie przestały być atrakcyjną rozrywką. Stereotyp jest trwały, mimo zmieniających się okoliczności historycznych wciąż żyje. Konstytutywną cechą procesu stereotypizacji jest nieustanna reprodukcja schematu myślowego. Wskazywał na to Homi Bhabha, który definiował stereotyp jako „formę wiedzy i identyfikacji oscylującą pomiędzy tym, co jest już znajome i zawsze "na swoim miejscu«, a czymś, co trzeba wciąż z niepokojem powtarzać" ${ }^{24}$, ponieważ nie da się takiego schematu udowodnić.

We współczesnym minstrel show autorstwa Delacroix, czarny maluje swoją twarz na czarno. Makijaż, który w dziewiętnastym wieku nakładał biały aktor, obśmiewający czarnych niewolników, trafia na twarze ich potomków. Stereotyp stworzony przez białych, teraz reprodukowany jest

24 H. Bhabha, Kwestia Innego: Stereotyp, dyskryminacja idyskurs kolonializmu, w: tegoż, Miejsca kultury, tłum. T. Dobrogoszcz, Kraków 2010, s. 57. 
przez czarnych. Spike Lee sugeruje, że podporządkowani są zniewoleni w swoich przedstawieniach. Aby zaistnieć w kulturze popularnej, muszą odnaleźć się w skonstruowanych wcześniej reżimach reprezentacji i bardzo często są zmuszeni powielać istniejące wyobrażenia, redukujące ich tożsamości. Notoryczne powielanie stereotypowego imaginarium nie zachodzi jedynie w bezpiecznej płaszczyźnie fikcji literackiej. Ten sam stereotyp ubiega się jednocześnie o status obiektywnej informacji. Wspomina o tym Ania Loomba, przywołując obraz „dzikusa” z Otella Williama Szekspira. W sztuce tej ludzie z „nowego kontynentu” opisywani są przez Maura jako ci, „którym głowy wyrastają ze środka piersi”25. Loomba zauważa, że wizerunek, który Otello przywołuje, jest analogiczny do podobizn z rysunków Theodora de Bry, flamandzkiego kartografa, rysownika i pisarza, który tworzył ilustracje do książek o amerykańskim kontynencie, nigdy tam jednak nie podróżując. Korzystał z obrazów i relacji kolonistów obu Ameryk. Stereotyp więc nigdy nie funkcjonuje wyłącznie jako pojedyncza fantazja - literackie wyobrażenie, ale aspiruje równocześnie do statusu obiektywnej informacji, nieustannie lawirując między fikcją i faktem. Co więcej, jego reprodukcja nie jest ograniczona ramami czasowymi. Jako mechanizm tworzenia społecznej różnicy, stereotyp jest częścią struktury dominacji, która nie jest procesem ahistorycznym. Wręcz przeciwnie, jak pisze Pierre Bourdieu w Męskiej dominacji, struktury dominacji są historyczne, „są wytworem niekończącego się procesu reprodukcji”26. Warunkiem efektywności karykatury, w ramach której konstytuowany ma być dyskryminowany podmiot, jest obok ciągłego reprodukowania, łączenie się z szeregiem innych fikcji. Tak produkowany stereotyp jest wielowarstwową, ambiwalentną konstrukcją, której nie da się jednoznacznie sklasyfikować jako nieprawdziwej. Bhabha podkreśla, że to forma bardziej skomplikowana niż zwyczajnie fałszywy obraz, wobec którego możemy powiedzieć: to nieprawda. Jest to taka strategia dyskursywna, która staje się kamuflażem, uzyskiwanym dzięki utrwaleniu cechy fantazmatu.

Delacroix każe swoim czarnym aktorom występować z blackaface, ponieważ taki makijaż ma dodać im „autentyczności”. Wykroczenie poza stworzoną w dziewiętnastym wieku podobiznę „,czarnucha” mogłoby być odczytane jako fałszywe, nieznane, wcześniej niewidziane, więc jakoby nieprawdziwe. Na tym być może polega również pokusa tworzenia obrazu wsi pogrążonej w oparach alkoholu, z chłopami wystającymi pod sklepem, skrzętnie powielona w Chtopakach do wzięcia.

25 A. Loomba, Kolonializm/Postkolonializm...

26 P. Bourdieu, Męska dominacja, tłum. L. Kopciewicz, Warszawa 2004, s. 47. 
Być może na nieodpartym uroku powtarzalności stereotypu zasadza się nieustanne powielanie w popkulturze tych samych, znanych wszystkim krajobrazów wiejskości.

Zamierzeniem Delacroix, podobnie jak Spike’a Lee, było rozbicie istniejących w amerykańskim społeczeństwie stereotypów o czarnych. Przechwytując blackface, reżyser zamierzał prowokacyjnie zdekonstruować typowe figury i romantyczne mity o poczciwym wuju Tomie, dobrej ciotce Jemimie, czarnej niani, zagnieżdżone w wyobraźni skolonizowanej wizją idealizującą niewolnictwo na plantacjach. Pomijając rozważania, czy i w jakim stopniu to przechwycenie mu się nie udało, istotnym wydaje mi się sam fakt nieuchronnego i koniecznego ustosunkowania się do istniejących już wyobrażeń i reprezentacji. Trajektorię działań Delacroix wyznaczają skonstruowane wcześniej reprezentacje czarnoskórych, znane wszystkim z popkultury krajobrazy plantacji bawełny i arbuzów. Podobnie jest również w przypadku obrazów wsi przebijających się do kultury popularnej. Postaci i sytuacje z Chtopaków do wzięcia są powidokami wyrytych w pamięci widzów i filmowców obrazów prowincji. Dobrotliwych bohaterów komedii U Pana Boga za piecem Jacka Bromskiego, pijanych, wysiadujących na ławce mieszkańców Wilkowyj z serialu Ranczo, kłótliwych, ale nieszkodliwych Kargula i Pawlaka z Samych swoich. Wieś wchodzi do telewizji na zasadach wyznaczonych przez reprezentacje komediowe i kabaretowe. Stereotyp jest trwały, umacnia się mimo zamieniających się miejscami etykiet komedii i reportażu, mimo przekształcających się okoliczności historycznych.

Kiedy nowy minstrel show święci triumfy, słupki oglądalności rosną, a blackface na powrót staje się najpopularniejszą podobizną czarnego, asystentka Pierre’a Delacroix, która od początku była krytycznie nastawiona do jego kontrowersyjnego przedsięwzięcia, wręcza mu zabawkę „wesołego Murzyna-skarbonki”. Wystarczy położyć na jego plastikowej dłoni monetę i nacisnąć, by trafiła ona prosto do ust małego „Murzyna”. Patrząc na nieustającą popularność wizerunku „zabawnego, pijanego wieśniaka”, reprodukowanego szczególnie w produkcjach telewizyjnych, a jak widać na przykładzie Chtopaków do wzięcia, przynoszącego wymierne zyski, taka plastikowa zabawka mogłaby powstać również w polskim kontekście.

\section{Intersekcjonalność opresji}

Istnieje niewiele rozpoznań, które opisywałyby sytuację osób nieheteronormatywnych na polskiej wsi. Pionierską na tym obszarze 
publikacją jest książka Niewidoczne (dla) spoteczności, dotycząca lesbijek i kobiet biseksualnych ze wsi i małych miast w Polsce, wydana w 2012 roku przez krakowską Fundację Przestrzeń Kobiet ${ }^{27}$. Autorki raportu w teoretycznym wstępie do publikacji opisują zjawisko dyskryminacji wielokrotnej. Przywołując m.in. teorię czarnego feminizmu, podkreślają fakt, że dyskryminacja płciowa łączy się zawsze z marginalizacją ze względu na orientację seksualną, pochodzenie etniczne, status ekonomiczny, wiek, niepełnosprawność.

Autorki Niewidocznych (dla) spoteczności, mówiąc o zjawisku przecinania się różnych form wykluczenia, które determinują nasze funkcjonowanie w świecie, nawiązują do działalności czarnych feministek z Bostonu. Afroamerykanki, które tworzyły razem Combahee River Collective, w 1977 roku opublikowały swój radykalny manifest. Definiowały w nim, na czym polega intersekcjonalność opresji, pisząc:

Jesteśmy oddane walce z opresją rasową, seksualną, opresją heteroseksualności i klasową i jako swoje zadanie widzimy rozwój integrujących te wymiary narzędzi analizy i praktycznych działań, opierając się na realiach, w których wszystkie te główne systemy opresji splatają się ze sobą. Synteza tych opresji tworzy warunki, w których żyjemy ${ }^{28}$.

Wieś borykająca się z problemem strukturalnego wykluczenia jest miejscem, w którym jak w soczewce skupiają się problemy związane z bezrobociem, niskim poziomem edukacji, niskimi zarobkami, słabą infrastrukturą techniczną i społeczną 29 . W produkcjach takich jak Chtopaki do wzięcia wielokrotna, przecinająca się na różnych poziomach dyskryminacja zyskuje swoją legitymizację. Kultura popularna umacnia hierarchie i podziały społeczne, a produkcje telewizyjne zapewniają ciągłość wcześniej wyrytym w wyobraźni obrazom i czynią z nich doskonale sprzedające się towary. Klasizm i seksizm w Chtopakach do wzięcia dotyczy zarówno kobiet, które są obiektami matrymonialnych poszukiwań, jak i mężczyzn, nad którymi zawieszony zostaje niezbywalny przymus posiadania partnerki. Patriarchat i heteronormatywność prezentowane są jako jedyne modele, na których opierać się mają relacje na wsi.

27 Niewidoczne (dla) spoteczności. Sytuacja spoteczna lesbijek $i$ kobiet biseksualnych mieszkajacych na terenach wiejskich $i w$ matych miastach $w$ Polsce. Raport z badań, red. J. Struzik, Kraków 2012.

28 The Combahee River Collective, A Black Feminist Statement, cyt. za: D. Cieślikowska, N. Sarata, Dyskryminacja wielokrotna - historia, teorie, przeglad badań, http://www.tea.org.pl/userfiles/file/Wielokrotna.pdf.

29 Tamże, s. 25. 
Seksizm, legitymizowany przez serial i porządkujący jednocześnie jego dramaturgię, prezentuje kobiety jako „zdobycze”, które zawsze ukazywane są w kontekście seksualnym oraz kategoryzowane ze względu na ich potencjalną „użyteczność” w małżeństwie. Chtopaki do wzięcia powielają i pogłębiają reżim tzw. tradycyjnego modelu rodziny, który miałby być dla wszystkich ludzi jedynym wzorem funkcjonowania i budowania bliskich relacji. Nie dopuszcza pozytywnego wartościowania aktywności seksualnej poza małżeństwem (szczególnie w przypadku kobiet).

Ofiarami klasizmu i seksizmu w opowieści o „wiejskich kawalerach”, którą co tydzień w niedzielny wieczór można obejrzeć w telewizji Polsat Play, są i kobiety, i mężczyźni. Istniejący od 2008 roku lifestyle’owy kanał odnotował w 2012 roku największy wzrost liczby swoich odbiorców. Rekordowy wynik jest motywowany m.in. emisją Chtopaków do wzięcia ${ }^{30}$. W artykule o popularności męskiego pasma telewizji Polsat w 2012 roku znajduje się również informacja o wzroście oglądalności kanału wśród mieszkańców miast o ludności powyżej dwustu tysięcy mieszkańców, widzów między dwudziestym a trzydziestym czwartym rokiem życia i o powiększeniu liczby widzów płci męskiej w stosunku do 2011 roku o dwadzieścia pięć procent.

Taka analiza profilu odbiorcy pozwala pokazać, że szowinistyczne treści generowane w serialu, które umacniają patriarchat, są opresyjne również w stosunku do mężczyzn, że męska supremacja nie jest jednolitą, niezróżnicowaną klasowo formą dominacji, która jednakowo traktuje wszystkich mężczyzn. Przykład serialu Morawskich pokazuje, jak historie mężczyzn ze wsi - niewykształconych, ubogich, często również chorych, z problemami alkoholowymi - stają się, jak się okazuje, rozrywką głównie dla młodych mężczyzn z dużych miast - modelowych widzów Polsat Play.

Warto przywołać w tym momencie bell hooks. Autorka Teorii feministycznej, polemizując z amerykańskim feministycznym separatyzmem kobiet z klasy średniej, pokazuje, że seksizm nie daje równych przywilejów wszystkim mężczyznom bez względu na to, z jakiej klasy społecznej pochodzą i jakiego są koloru skóry. W rzeczywistości patriarchalnej mężczyzna jest opresorem, ale jest również opresjonowany. Ta skomplikowana sytuacja może być powodem obawy, że wskazanie cierpienia po stronie mężczyzn umniejszyłoby w jakiś sposób znaczenie seksizmu. Jednak hooks wyjaśnia współistnienie dwóch rzeczywistości: seksistowskiej dominacji mężczyzn nad kobietami, przy równoczesnym istnieniu sytuacji,

30 http://media2.pl/badania/99531-Rekordowy-rok-Polsat-Play.-Przybywawidzow-z-wiekszych-miast.html. 
kiedy mężczyźni cierpią z powodu sztywnych ról płciowych ${ }^{31}$. Przykładem takiego stanu jest właśnie uprzedmiotowienie i utowarowienie frustracji ubogich i niewykształconych mężczyzn ze wsi, których wyobrażenie o egzystencji zostało ukształtowane w oparciu o jedyny model małżeństwa i tradycyjnej rodziny. Dostrzeżenie, że mężczyźni ze wsi padają w tych reprezentacjach ofiarą intersekcjonalnej dominacji klasowych i seksistowskich stereotypów, nie umniejsza znaczenia represyjnej władzy nad kobietami, które - na wsi szczególnie - dotknięte są schematycznymi wyobrażeniami o obyczajowości oraz ograniczane esencjalizującymi definicjami kobiecości i niemożliwości osiąnnięcia niezależności innej, niż tylko w heteroseksualnym małżeństwie. I mężczyźni, i kobiety nie mają dostępu do edukacji seksualnej, antykoncepcji, a aktywność seksualna poza małżeństwem, która mogłaby być wartościowana pozytywnie, zderza się z tradycyjną wizją małżeństwa i rodziny, umacnianą przez Kościół.

\section{Wnioski. Postkolonializm i czarna myśl feministyczna a epistemologia wsi}

Mam nadzieję, że analiza omawianych przeze mnie dokumentalnych reprezentacji chociaż po części ujawniła, w jaki sposób konstruowane są reżimy widzialności wsi, które wynikają z ustalonego porządku dominacji. Warunkiem możliwości zaprojektowania niehierarchicznego świata jest przekraczanie wyznaczanych przez ten porządek granic poznania. Przyglądanie się reprezentacjom nie powinno kończyć się jedynie na stwierdzeniu, jak dalekie są one od prawdy. Być może jest to najmniej istotna kwestia. Myślę, że chodzi raczej o to, by zdawać sprawę, w jaki sposób takie wyobrażenia działają - czy konstruują społeczne różnice, w jaki sposób są sprawcze, jakie są ich polityczne konsekwencje.

W podsumowaniu analizy Warszawy do wzięcia i Chtopaków do wzięcia chciałabym zwrócić szczególną uwagę na wnioski, jakie płyną dla myślenia o równości, kiedy przyglądamy się konstruowanym społecznie różnicom zatopionym w reprezentacjach. Zarówno projekt reedukacji, o którym opowiada film Warszawa do wzięcia, jak i dychotomizujące narracje o mitologicznej opozycji miasta i wsi, na których opierały się oba filmowe przykłady, ujawniają, w jaki sposób różnica traci swój emancypacyjny charakter. Wspiera się na niej konstruowana figura inności, która coraz bardziej zawłaszcza naszą wyobraźnię. Najbardziej doniośle ujawniła się chyba w przypadku problemu tzw. wyrównywania szans.

31 b. hooks, Teoria feministyczna..., s. 69. 
Stało się tak dlatego, że równość była tutaj w najlepszym przypadku tylko abstrakcyjnym założeniem, jakimś dalekim, hipotetycznym punktem dojścia. Idea równości realizuje się, jak sądzę, dopiero wtedy, gdy jest aksjomatycznym punktem wyjścia.

Ostatnie głosy w nauce i kulturze ${ }^{32}$, budujące paralelę między pańszczyzną chłopstwa i niewolnictwem, odzyskują nieobecną w szlachecko-nacjonalistycznej narracji historiografię wsi i losów polskich chłopów. Narracje wspierane często przez teorię postkolonialną, oferują wykluczonym nową wiedzę o ich doświadczeniach. Krytyka postkolonialna, co starałam się pokazywać, może przydać się również w celu problematyzacji transformacji społeczno-gospodarczej oraz do analizy opowieści, które ją uprawomocniają. Od Gayatri Spivak możemy uczyć się, jak podczas prób wzmacniania głosów nieobecnych nie wpaść w pułapkę esencjalizacji podporządkowanych innych i jak nie pozbawiać ich płci społeczno-kulturowej. Szczególnie ważną kwestią jest dla Spivak rola feministycznej intelektualistki w odnajdywaniu głosu podporządkowanej i pytanie o warunki możliwości obiektywizmu w procesie translacji doświadczeń różnych kobiet.

W Wiedzach usytuowanych Haraway pisała o odpowiedzialnej badaczce, która pozycjonuje swój punkt widzenia, ujawnia kontekst społeczno-kulturowy, w którym funkcjonuje, uwidaczniając w ten sposób mechanizmy władzy, której jest przedstawicielką. Tylko takie działanie pozwala na przekraczanie granic wyznaczanych nam przez płeć, klasę, rasę. Projektowanie niehierarchicznego świata wymaga wyjścia poza własne uwarunkowania.

W odróżnieniu od teoretyków i teoretyczek postkolonializmu, które najczęściej wyznaczały trajektorię władzy zorganizowaną wertykalnie - od kolonizatora do kolonizowanego, czarne feministki wypracowały nowe narzędzia pojęciowe, które wzbogacają naszą wiedzę o skomplikowanej strukturze dominacji formowanej historycznie. Przywoływana analiza intersekcjonalna, rozwijana przez czarne feministki, to narzędzie, które nie tylko - jak dekolonialna krytyka - wyposaża nas w nową wiedzę o podporządkowanych, ale przede wszystkim oferuje nowy sposób poznania. Dzięki tej perspektywie możemy konceptualizować władzę jako wielopoziomową strukturę, w której splatają się ze sobą rasa, klasa, płeć, a opresja jest uwewnętrzniana przez jednostkę. Sądzę, że analiza intersekcjonalna pozwala nam łączyć historię z biografią, a do odzyskiwa-

32 M.in. spektakl W imię Jakuba S. Moniki Strzępki i Pawła Demirskiego oraz jego recepcja, twórczość zespołu R.U.T.A. oraz feministycznego zespołu Pochwalone, debata publiczna o chłopskiej genealogii społeczeństwa polskiego. 
nych przez postkolonializm historii włącza konkretne, jednostkowe doświadczenia.

Rozbijanie patriarchatu i wszelkich rodzajów dominacji potrzebuje siły, która powinna nieustannie rewidować własne założenia i sprawdzać jednocześnie, w jakie hierarchiczne schematy sama się wikła. Doświadczenia kobiet egzystujących na marginesach geograficznych, ekonomicznych, społecznych to doświadczenia daleko wykraczające zarówno poza akademicki feminizm oraz jego liberalne skrzywienie. Również radzenie sobie z takimi doświadczeniami niewiele ma wspólnego z proponowanym przez Graff feminizmem, definiowanym przez nią jako „pewien niszowy światopogląd, pewna wizja wycinka rzeczywistości społecznej"33. W takim kształcie feminizm nie stanie się siłą i działaniem przekształcającym naszą świadomość, w takim jego rozumieniu nie ma miejsca na doświadczenia różnych kobiet ze wsi: starszych, chorych, kobiet LBTQ, młodych, tych, które jak bohaterki Warszawy do wzięcia próbują się ze wsi wydostać, jak i tych, które dopiero co do niej wyemigrowały.

Wiedza męskiego zachodniego badacza nie ma lokalizacji - chciałaby być wszędzie i w rezultacie jest nigdzie. Na pytanie, jak być usłyszaną, bell hooks, Donna Haraway, Patricia Hill Collins odpowiadają postulatami cząstkowej, umiejscowionej i nieuniwersalnej perspektywy - elementami szczególnie istotnymi dla feministycznych epistemologii. Ujęcie intersekcjonalne i perspektywa marginalna to narzędzia, dzięki którym badaczki feministyczne mogą zapytać o kobiety funkcjonujące na marginesach ekonomicznych, geograficznych i społecznych. Sądzę, że problematyzacja systemu patriarchalnego jako wielopoziomowej struktury, w której zajmujemy różne pozycje, może szczególnie wzbogacić naszą wiedzę o opresji kobiet. Łączna analiza, uwzględniająca zarówno kwestię płci, jak i klasy społecznej, rasy, orientacji seksualnej, wieku umożliwia nam mówienie o konkretnych doświadczeniach, pozwala ustrzec się przed marginalizacją kobiet w feministycznych działaniach, a przede wszystkim dostarcza wiedzy niezbędnej do tworzenia zróżnicowanej wspólnoty.

33 A. Graff, Obca w kranie patriarchatu...

Doświadczenia kobiet egzystujących na marginesach geograficznych, ekonomicznych, społecznych to doświadczenia daleko wykraczające zarówno poza akademicki feminizm oraz jego liberalne skrzywienie 
Monika Borys (1989) - doktorantka w Zakładzie Filmu i Kultury Wizualnej w Instytucie Kultury Polskiej na Uniwersytecie Warszawskim. Interesuje się filozofią feministyczną, teorią postkolonialną oraz kulturą wizualną. Obecnie zajmuje się badaniem (nie)widzialności polskiej wsi po 1989 roku.

\section{Dane adresowe:}

Instytut Kultury Polskiej UW

ul. Krakowskie Przedmieście 26/28

00-927 Warszawa

e-mail: nikaborys@gmail.com

Cytowanie: Monika Borys, Rasa, klasa, pteć i wieś. Feministyczne epistemologie marginesu, „Praktyka Teoretyczna” nr 4(10)/2013, http://www. praktykateoretyczna.pl/PT_nr10_2013_Epistemologie_feministyczne/02.Borys.pdf (dostęp dzień miesiąc rok)

Author: Monika Borys - PhD candidate in the Institute of Polish Culture of the University of Warsaw (Section for Film and Visual Culture). Her principal research interests lie in the field of feminism, postcolonial studies and visual culture. She is now preparing her dissertation on (in)visibility of the countryside after 1989. Title: Race, Class, Gender and Countryside. Feminist Epistemologies of the Margin Summary: In my article I am trying to explore ways in which Polish feminism can expand its knowledge about woman living in the countryside. To this purpose I recall theories from black feminist thought and postcolonial studies which help to enrich subaltern epistemologies. To renegotiate regimes of visibility, which limit our imagination, I use these theories to analyze pop culture representations of rurality (documentary Warszawa do wzięcia and docusoap Chtopaki do wzięcia). Referring to bell hooks' theory of the margin and to postcolonial writings of Gayatri Chakravorty Spivak and Donna Haraway's concept of situated knowledges, which all help to develop our knowledge about different kinds of oppression and their intersectionality, I want to draw attention to these dimensions of sexism which don't fit into rigid categories of "problems faced by woman from big cities".

Keywords: countryside, theory of margin, subalterns, situated knowledges, intersectionality 